\title{
Altering lamb supply: a case study of late lambing in Southern New Zealand to meet market specifications
}

\author{
D.R. STEVENS ${ }^{1}$, G.S. B AXTER ${ }^{2}$ and J.D. TURNER ${ }^{3}$ \\ ${ }^{l}$ AgResearch, Invermay Agricultural Centre, PB 50034, Mosgiel \\ 23 Pukaki St, Gore \\ ${ }^{3}$ Southern Plant and Animal Production Research, 1 Gertrude Street, Gore \\ david.stevens@agresearch.co.nz
}

\begin{abstract}
Coopworth ewes in a farm system study mated from 21 June had a lambing percentage (lambs weaned/ ewe mated) of $126 \%$ in Southland New Zealand (lat $\left.46^{\circ} 12^{\prime} \mathrm{S}\right), 13 \%$ lower than the farm September lambing average of $139 \%$. Total farm production records showed that $221 \mathrm{~kg} / \mathrm{ha}$ of lamb meat and 127 $\mathrm{kg} / \mathrm{ha}$ of wool were produced. Pasture production was $15800 \mathrm{~kg} \mathrm{DM} / \mathrm{ha}$, while $58 \%$ of the farm area was used for silage making in late October. Extra inputs required included fertiliser where silage was made, labour for silage feeding in winter, the costs of silage making and feeding out, concentrate feeds during winter, and extra shearing costs. Savings were made in crutching costs and labour costs at lambing due to lambing ease. November lambing systems provide the opportunity to produce heavyweight lambs for slaughter at 9 to 11 months of age but price structures need to account for the increased production costs.
\end{abstract}

Keywords: Coopworth, farm systems, November lambing, pasture production

\section{Introduction}

Market trends and lamb supply are again putting pressure on farmers to produce more lambs out of season. This trend has emerged as a feature in the 1970's (Herlihy 1970) and again in the 1980's (McNatty 1986). Recent improvements in on-farm performance have seen a shift in the spread of lamb supply as farmers recognise the efficiencies from the matching of feed supply and demand subsequently condensing the lamb supply away from the shoulders of the season. Meat companies are therefore interested in economic ways of shifting lamb supply to meet market requirements.

Spring is a key period when heavy weight carcases for processing and subsequent sale in chilled meat markets are in short supply. On-farm options to provide lambs at this time in Southern New Zealand include keeping spring born lambs, increasing hogget lambing as these lambs are often born in November, or shift some ewes to lamb in November. The two later options can provide heavy weight lambs less than 12 months of age for slaughter during September and October.

Shifting lambing dates and lamb supply will have a significant impact on both feed requirements and farm costs. This paper outlines the results of a farm systems study that investigated the potential to produce lambs born in November and slaughtered at 9-11 months of age to improve the supply of young lambs in early spring. A whole farm system approach was chosen to gauge the full effect of the impacts of shifting lambing date from September to November. This research measured the impacts of a large change in the farming system on the productivity of the enterprise.

\section{Materials and methods}

A whole farm system study was developed to document sheep and pasture production outcomes when late lambing was practiced. A two-year study starting in March 1988 used natural mating of Coopworth ewes in late June (joining date 21 June) to provide lambs born in November and weaned in late February. This provided lambs of 9 to 11 months of age for slaughter during August, September and October. A stocking rate of $15.5 \mathrm{SU} / \mathrm{ha}$, comprising of 13 ewes and 3.5 hoggets per hectare, was chosen on a total farmlet area of 12.8 ha, making a total of 160 ewes and 45 hoggets. Spring pasture surpluses were saved as silage and fed to lambs on a feed pad from May to September. The lambs were chosen for the feed pad to reduce the pressure on pastures, make silage feeding simple and to ensure that ewes were mated at pasture. Lambs were fed ad-libitum silage plus a concentrate ration based on $200 \mathrm{~g} / \mathrm{d}$ barley and $50 \mathrm{~g} / \mathrm{d}$ rape seed meal per lamb.

A ram to ewe ratio of 1:30 was used during the first year and 1:80 during the second year. Ewes were mated for 2 cycles by harnessed Coopworth rams with crayons being changed every 17 days.

Pasture cover was measured monthly. Feed was allocated at each stock movement according to a feed budget (Table 1). Ewes were continuously stocked from lambing to tailing, and were rotationally grazed during the rest of the year. Hoggets and lambs were 




rotationally grazed with shifts being every 3 to 4 days during spring summer and autumn, and daily during winter. Pasture botanical composition was determined on samples from representative areas of the farmlet each month. Feed intake was determined from preand post grazing herbage mass by difference. Pasture growth was calculated from monthly summaries of pasture cover and feed intake during the month.

Data on the lambing percentage, lamb survival, and lamb weaning weight as well as stocking rates, pasture production and utilisation, lamb carcass weight and wool production are reported. Average pasture production data from five years of previous farm systems studies on the same property using standard September lambing practises are used as a comparison. Data on the reproductive performance of a September lambing system was gathered from the surrounding farm, which had the same genetic line of Coopworth sheep, and used similar pasture management practices. Management information from the November lambing system is also presented.

\section{Results and discussion}

The Coopworth ewes (fleece-free weight of $56 \mathrm{~kg}$ at mating) achieved an average lambing percentage of $126 \%$, ewes mated to lambs weaned (Table 2). This result was $13 \%$ lower than the whole farm September lambing average of $139 \%$. There were 142 lambs born per 100 ewes mated, while the death rate from birth to weaning was 13 lambs per 100 lambs born in both years. The percentage of ewes not lambing (dry) was $1 \%$ in Year 1 and $0 \%$ in Year 2. With the continual improvement of Coopworth and Romney flocks, along with the introduction of East Friesian and Finn genetics the average lambing percentage has risen to $135 \%$, with top farmers averaging $140-150 \%$. The farm average of this line of Coopworths (139\%) is similar to current results in the industry. The results from November lambing may be different now than at the time of this study with the increased use of the Finn, as the Finn cycles for 2 to 3 months later and has a higher ovulation rate throughout (Wheeler \& Land 1977). The number of multiple ovulations in ewes does decline throughout the breeding season. Montgomery \& Hawker (1987) found that the proportion of Romney and Perendale ewes having multiple ovulations declined from 1 in April to 0.45 by July in ewes with a longer breeding season.

The average carcass weight achieved (Table 3 ) was $17.7 \mathrm{~kg}$, while $221 \mathrm{~kg}$ lamb meat was produced per hectare. The average carcass weight of male lambs was $19.6 \mathrm{~kg}$ while female lambs were sold at a lower weight of $14.6 \mathrm{~kg}$ to avoid grading penalties due to excess carcass fat. This tendency towards over fatness 
was a feature of lambs fed predominantly on silage and grain during the winter, similar to the result reported by Stevens et al. (1989). Shifting lambing to November also meant that an anthelmintic treatment was required before weaning. Lambs exhibited symptoms of internal parasite burdens during January in Year 2, requiring an anthelmintic and increased the range of live weights at weaning.

Wool production (Table 3) of $8.2 \mathrm{~kg} / \mathrm{SU}$, when expressed using the $15.5 \mathrm{SU} / \mathrm{ha}$ standard, compares well to the Southland model that produces $5.6 \mathrm{~kg} / \mathrm{SSU}$. A total of 28.4 sheep were shorn per hectare and shearing was twice yearly for all stock. Ewes and hoggets were shorn in March and November eliminating the need for crutching. Lambs were shorn in March and September to provide clean lambs before and after being feedlotted. The wool production per head was similar to standard lambing systems but the extra lambs kept for twelve months provided a significantly greater amount of wool per hectare. The decision to shear the lambs in this system may depend on the type of feedlot, the need to clean lambs up before slaughter, and the relative prices of shearing and wool sales.

Both pasture and animal production from the November lambing system was relatively high compared to the Southland and South Otago intensive sheep finishing farm monitoring model. The overall stocking rate (ewes plus hoggets) of $15.5 \mathrm{SU} /$ ha is higher than the Southland average of 13.5 $\mathrm{SU} / \mathrm{ha}$ for the intensive sheep finishing model (Ministry of Agriculture and Forestry 2002). The stocking rate did not include the lambs because they were held over winter on the feed pad. The feed intake (Figure 1) showed 
that the total mid-winter feed requirement of each stock class was at least that usually allocated to a mature ewe, with a total mid-winter stocking number of $29 \mathrm{head} / \mathrm{ha}$. The measured feed intakes were relatively similar to those budgeted (Table 1) with the noted exception of lambs on silage, eating between 0.9 and $1.1 \mathrm{~kg} \mathrm{DM} / \mathrm{d}$ compared to a budgeted figure of $1.3 \mathrm{~kg} \mathrm{DM} / \mathrm{d}$. This was despite the effort to make high quality silage before the appearance of significant amounts of seed head in the silage crop, and the addition of $200 \mathrm{~g} / \mathrm{d}$ barley and $50 \mathrm{~g} / \mathrm{d}$ rapeseed meal per lamb. The silage made had an energy concentration of $11.2 \mathrm{MJ}$ $\mathrm{ME} / \mathrm{kg} \mathrm{DM}$ and a protein concentration of approximately $14 \%$. These low intakes resulted in lamb liveweight gains during winter of between 75 and $180 \mathrm{~g} / \mathrm{d}$.

The feed use profile (Figure 2) shows clearly how much extra feed was required during winter with only $42 \%$ coming from pasture in July. Figure 2 also shows the significant amounts of feed being diverted to silage making during August, September and October. A current example of a high performing Southern South Island sheep system of a similar stocking rate is modelled in Figure 3. This uses a similar stocking rate of ewes and hoggets to the study system, a commonly attained ewe liveweight of $65 \mathrm{~kg}$ and a lambing percentage of $150 \%$. The comparison of this system and the November lambing system (Figure 3) shows the difference in feed
Figure 2 The daily use of pasture and supplements in a November lambing system with all lambs being held over for slaughter at 9 to 11 months of age expressed on a per hectare basis.
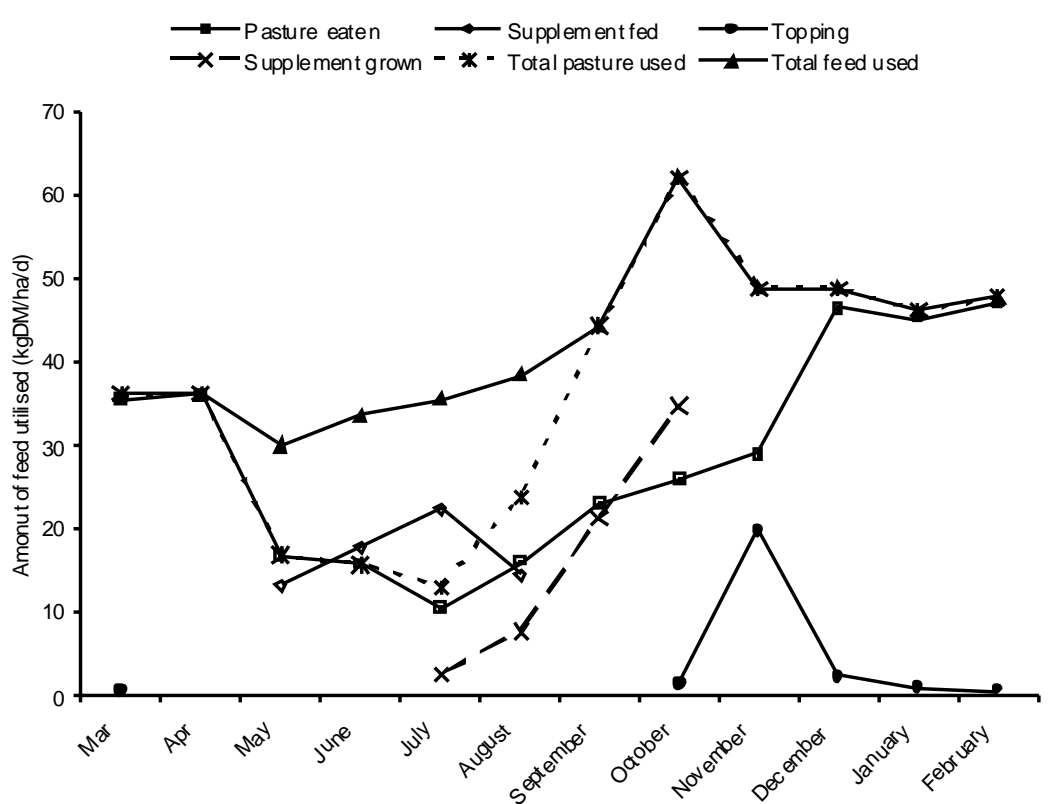

Figure 3 Feed requirements of a September lambing system achieving 150\% tailing percentage from $65 \mathrm{~kg}$ ewes stocked at 13/ha plus 3.5 hoggets/ ha, selling lambs from weaning in early December until mid-April, with $50 \%$ of lambs sold by mid-February compared to the measured feed requirements of a November lambing system running $55 \mathrm{~kg}$ ewes achieving $125 \%$ lambing at the same stocking rates of ewes and hoggets but taking lambs to slaughter between August and November, and the pasture growth rates of a Waikoikoi clay loam soil under September and November lambing systems in Southland.

* September lambing feed requirement $\longrightarrow$ Novem ber lam bing feed requirem ent

- September lambing pasture growth rate $\longrightarrow$ Novem ber lam bing pasture growth rate

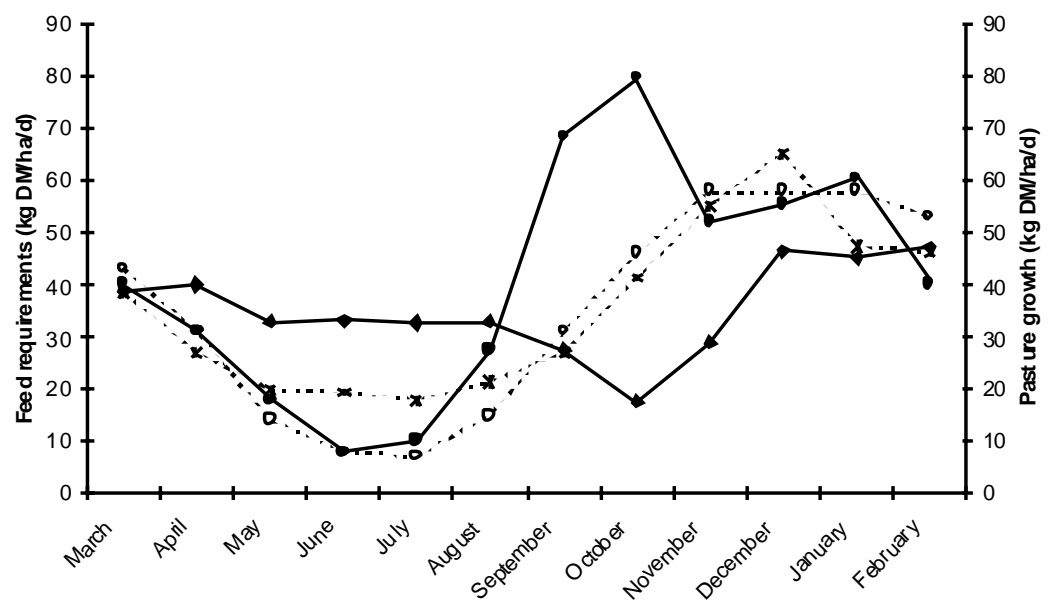

requirements between the systems. The September lambing system matches the pasture production profile of a common regional soil type more closely than the November lambing system. The difference 
in spring pasture growth was converted to silage as depicted in Figure 2. The change in feed demand profile in the November lambing system also meant that some paddocks grazed in July were subsequently not needed for grazing again until after silage was made in late October. This gave the impression of very early shutting up of pasture for silage, but this was an artefact of the shift in the feed requirements of those animals on pasture. This meant that lambs were released to pasture earlier in the second year of the study, on August $9^{\text {th }}$, compared to September $4^{\text {th }}$ in the first year.

The feed profile also shows a shift in peak pasture production from the traditional time of November (Figure 3) into October. The main aim of making silage early in this system was to provide high quality silage for the lambs on feed lot. The shutting up of large areas $(58 \%)$ of the farm during August, September and October for feed conservation provided the opportunity for high pasture growth rates during this time (Figure 3 ). This was directly related to the exclusion from grazing at this time as the average pasture growth rates recorded at Woodlands Research
Station during the two years of this experiment were 13, 28 and $49 \mathrm{~kg} \mathrm{DM} / \mathrm{ha} / \mathrm{d}$ and within $1-3 \mathrm{~kg} \mathrm{DM} /$ $\mathrm{ha} / \mathrm{d}$ of the long term average (C Smith unpublished data). The subsequent making of silage in late October then saw the November growth rate of those pastures slow down though was still similar to the standard September lambing system (Figure 3). Total pasture production in the November lambing system averaged $15800 \mathrm{~kg} \mathrm{DM} / \mathrm{ha}$, consisting of $61 \%$ ryegrass, $20 \%$ white clover and $19 \%$ other grasses. The September lambing system represented here grew $12800 \mathrm{~kg} \mathrm{DM} /$ ha, with a similar botanical composition (G Baxter unpublished data). The total amount of silage made equated to $3300 \mathrm{~kg} \mathrm{DM} / \mathrm{ha}$, or $42 \mathrm{t}$ for the $12.7 \mathrm{ha}$. Only $2100 \mathrm{~kg} \mathrm{DM} / \mathrm{ha}$ was fed back out. This led to the earlier turnout in the second year, and provides some opportunities for other uses of the extra feed such as selling the crop or buying in other stock in spring or winter.

The making of large amounts of silage had several significant effects on the inputs required. The first was the requirement of extra maintenance fertiliser. This was estimated to be the equivalent of $200 \mathrm{~kg} / \mathrm{ha}$

of $30 \%$ potassic superphosphate over the $58 \%$ of the farm made for silage. Some extra feed (5.5t DM or $430 \mathrm{~kg} \mathrm{DM} / \mathrm{ha}$ ) was conserved as hay during January but this extent of feed conservation was considered similar to a normal September lambing system. Using silage adds significant costs. These may include the cost of making, capital costs of both bunkering and feeding out including machinery, and often will add the cost of building a feed pad. Extra labour required is estimated to be for approximately 100 days during winter, as silage was fed from mid-May until midAugust. The regular shearing saw an estimated 30 extra 
sheep shorn/ha/yr. compared with a once a year shearing policy, though reduced crutching by 26 sheep/ha/yr. Another saving was in labour during lambing. There were relatively few birthing difficulties and no vaginal prolapses (bearings), removing the potential need for a lambing shepherd.

The relative costs of the November lambing system are compared to a September lambing system in Table 4. The major contributors to the cost of the system were the silage making (34\%) and the extra concentrate feed required $(26 \%)$. Shearing, fertiliser and vehicle use were also major contributors (7$11 \%$ ) while labour and animal health had only a small influence on the extra costs. These increases amounted to an extra $\$ 31 /$ lamb sold, suggesting a premium of at least that amount between lambs sold during the normal season and those sold in spring. This did not include the lower lamb meat produced per hectare, though this was offset by an increase in wool production. If extra wool was allowed for then the net price of wool per $\mathrm{kg}$ would need to be at least $68 \%$ of the price of lamb per $\mathrm{kg}$. For example, if the price of lamb was $\$ 4.00 / \mathrm{kg}$ then average wool price would need to be greater than $\$ 2.72 / \mathrm{kg}$ greasy. This analysis has been done without consideration of any extra capital requirement for machinery or feedlots.

\section{Conclusions}

Lambing in November lowered lambing percentage by $14 \%$ but provided easy lambing conditions and high carcass weights during the following early spring. High stocking rates were maintained but costs of production may be greatly increased. A partial budget indicated that the premium per lamb overwintered would have to be $\$ 31$ or greater to displace a current high performance sheep system.
High production may be achievable, but will require extra capital expenditure to run as a system. The use of a small flock lambing late within a standard system may provide an opportunity to maximise both production and pasture quality objectives.

\section{ACKNOWLEDGEMENTS}

Many thanks go to Challenge Meats Ltd and the late Mr Doug Lee for their support in this research. Thanks also go to DSIR Grasslands Gore farm staff.

\section{REFERENCES}

Herlihy, G. J. 1970. The spread of lamb and mutton kill in Southland from the Producer viewpoint. The Agricultural Production Council. pp. 35-61.

McNatty, K. 1986. Out of Season Lamb Production. Proceedings of an out of season lamb production course. Ministry of Agriculture and Fisheries, Flock House. 22-23 July 1986.

Ministry of Agriculture and Forestry 2002. Farm Monitoring Reports. http://www.maf.govt.nz/ mafnet/ rural-nz/statistics-and-forecasts/farmmonitoring/index.htm

Montgomery, G.W.; Hawker, H. 1987. Seasonal reproduction in ewes selected on seasonal changes in wool growth. Journal of Reproduction and Fertility 79: 207-213.

Stevens, D.R.; Lee, D.M.; Dillon, M.B.; Turner, J.D. 1989. A co-operative programme to extend lamb production in Southland. Proceedings of the New Zealand Grassland Association 50: 73-78.

Wheeler, A.G.; Land, R.B. 1977. Seasonal variation in oestrus and ovarian activity of Finnish Landrace, Tasmanian Merino and Scottish Blackface ewes. Animal Production 24: 363-376. 